Original research article

\title{
"It is better to treat a Vietnamese woman than a Czech": Strange interactions between healthcare professionals and women in the context of perinatal care
}

\author{
Alena Glajchová * \\ University of West Bohemia, Faculty of Philosophy and Arts, Department of Sociology, Pilsen, Czech Republic
}

\begin{abstract}
The periods of pregnancy, childbirth and becoming a mother are some of the most important moments in a woman's life - and they are usually experienced within a healthcare institution. However, contact with the healthcare system during these periods can bring a number of difficulties and barriers for women with other nationality than Czech and affect interactions between them and healthcare professionals. The aim of this text is to explain how the category "foreigner" is established, and what "strangeness" means for healthcare professionals in relation to women within the context of perinatal care. The qualitative research was focused on healthcare professionals' experiences with women of different nationality. During the research, several in-depth interviews, non-participant observations and informal interviews were conducted. Healthcare professionals distinguish two categories of women who were not born in the Czech Republic - "our foreigners" and "migrants" - with regard to geographical and cultural proximity within their everyday practice. Foreignborn women are perceived by healthcare professionals as "obedient" patients who don't disrupt the routine of everyday medical practice. However, "strangeness" is not interpreted by healthcare professionals on the basis of a different nationality, but mainly due to problematic communication, non-cooperation, mistrust, and challenging women.
\end{abstract}

Keywords: Communication; Language barriers; Migration; Perinatal care; Stigma; Strangeness

\section{Introduction}

The experiences of pregnancy and childbirth are among the most important moments in the life of a woman who is becoming a mother. Evaluating these experiences usually focusses on experiences in institutional care. Women are in close contact with healthcare professionals before, during, and after childbirth. These professionals are crucial in the delivery process and thus also in women's experiences of these important events. The process of transitioning into becoming a mother is more significant for migrant women who find themselves in a foreign country. Migrant women experience a double transition: they are trying to integrate into a new society, facing many socio-cultural barriers, and at the same time, dealing with the ideology of "good motherhood" - i.e being "a good mother as a foreigner" (Liamputtong, 2006, p. 44). Pregnancy is often their first entry into the healthcare system - and perhaps even their first contact with the majority society. Feeling at a disadvantage affects not only their integration but also their entire life experience.

The theoretical framework for exploring the proposed theme includes the concept of vulnerability, defined as "vul- nerability to threat, harm, and exposure to risk" (Aday, 1994, p. 487). In the context of health, the concept of vulnerability is related to persons experiencing reduced autonomy - the loss of control over their own body - and persons exposed to the risk of impaired health, inevitably associated with weakness, helplessness, or dependence. This concept is exacerbated by social inequalities and power relations, and is key to understanding the issues confronting disadvantaged and marginalised individuals or groups in society. The disadvantaged position of vulnerable individuals is often connected with discrimination because of their vulnerable status, which also occurs as a cause of stigma formation.

The migrant population is one of the most vulnerable groups in a population (Rogers, 1997). As for migrant women in the context of perinatal care, studies by those such as Balaam et al. (2013) and Robertson (2015) point to:

- poor access to health care;

- lower quality of healthcare received;

- delay in prenatal care;

- cultural differences;

- communication barriers;

- discriminatory practices and prejudices on the part of healthcare professionals.

\footnotetext{
* Author for correspondence: Alena Glajchová, University of West Bohemia, Faculty of Philosophy and Arts, Department of Sociology, Univerzitní 8, 30614 Pilsen, Czech Republic; e-mail: alenag@kss.zcu.cz http://doi.org/10.32725/kont.2019.041 
In addition to language barriers, the issue of health insurance is the most frequently discussed topic in Czech society, and it concerns not only women of reproductive age but also other foreigners residing in the Czech Republic (Hnilicová et al., 2012).

The aim of this text is to explain how healthcare professionals define migrant women and "strangeness" on the basis of their experiences, and how these categories are established in interactions between them in the context of perinatal care. The findings come from qualitative ethnographic research that focussed on the healthcare professionals' perspective and their experiences with care provided to migrant women. However, I will discuss not only migrant women, but also Czech women - all women with whom healthcare professionals come into contact in their everyday medical and nursing activities (hereinafter referred to as medical practice). In interpreting the partial findings of my research, I use the term "strangeness" in the way this term is used by healthcare professionals in relation to all women - that is, in terms of proximity, distance, difference and dissimilarity, common to both groups, and what healthcare professionals consider positive. The use of the notion of "strangeness" allows us to better grasp the issue of the relationship and the communication between these participants. The label "healthcare professionals" is used in this text for easier reading; it is also the label identifying the findings from interviews conducted with women (midwives, nurses, doctors) and with men (doctors, obstetricians).

In previous literature on the same or similar issues, I mention the key study by Ema Hrešanová (2008). She conducted ethnography of two Czech maternity hospitals focussing on the organizational context. Her partial findings revealed how healthcare professionals in maternity hospitals view women ("clients") and how they categorize them. Other studies (Hašková, 2001; Hrešanová, 2011; Hrešanová and Glajchová, 2018; Hrešanová et al., 2008; Slepičková and Šmídová, 2014) focussed on the organization of midwifery, women's experiences with the healthcare system in childbirth, and the attitudes of gynaecologists and obstetricians regarding their own evaluation of their profession. Nevertheless, I note that there are few studies from the perspective of healthcare professionals in the Czech context, and few that focus on migrant women in the context of perinatal care - their relationship with healthcare professionals. Despite its importance, the topic appears to be an under-researched area in the Czech context. Contact with healthcare professionals in the institutional context is of great importance to pregnant women and those giving birth and becoming mothers. The topic gains importance in light of the increasing number of migrants residing in the Czech Republic. Since 2014, the number of migrants has been increasing by approximately 20 to 40 thousand individuals every year. The total number of migrants reached 524,142 in 2017, of which 228,058 were women (Czech Statistical Office, 2018). By age group, the largest group of women are of reproductive age (126,015 women aged 20-44). Provisional data from 2018 again show an increase in the number of foreigners, which rose to 566,931 (of which 244,768 were women). These numbers are include foreigners staying on long-term visas or with one of the types of residence permits, such as registered citizens of the European Union, and not asylum-seekers. It can be presumed that there is a corresponding increase in the number of women seeking health care during pregnancy and childbirth. This topic undoubtedly affects healthcare professionals who often find themselves in difficult situations and face challenges that are mostly of an institutional or a sociocultural nature. For that reason, I consider the qualitative methodology suita- ble for obtaining a better insight into the professionals' experiences and perspectives.

\section{Materials and methods}

The data come from qualitative research focussing on healthcare professionals' experiences with migrant women in the context of perinatal care in the Czech Republic. I carried out the ethnography of one healthcare facility, specifically the gynaecological-obstetric ward (including prenatal department and counselling, delivery room and neonatal ward), where I conducted several in-depth interviews, non-participant observation and informal interviews. For the purpose of data triangulation, I also conducted several in-depth interviews with healthcare professionals in other institutional facilities of perinatal care. The inclusion of more healthcare facilities enhanced the validity of the research while providing more comprehensive insights into the researched issue (Hendl, 2005). In total, I conducted in-depth interviews with 35 healthcare professionals (8 male doctors, 1 female doctor, 7 nurses, and 19 midwives) from 9 healthcare facilities, between June 2017 and May 2018.

Access to the facilities required an approval to conduct the research, in the form of a written contract. Approval from the management of the healthcare facility gave me the opportunity to contact particular healthcare professionals and move freely around the ward. In order to maintain privacy, the research was limited to areas outside of the examination and hospital rooms. Informants were male doctors, female doctors and especially midwives and children's nurses (whose work requires extensive contact with women in the context of healthcare). I usually contacted the informants through an initial contact with the senior doctor or nurse in charge of the department. Thereafter, they referred me to another member of their team, whether this be a male doctor, a female doctor, a ward nurse, a midwife or a children's nurse. I asked for their consent to participate in my research and the interview. Other informants were selected by the "snowball" method, both within and outside the institution. Only one criterion was used for the selection of informants: experiences caring for migrant women. The length of practice was taken into account, but none of the participants had less than five years of experience. I considered this relevant in light of the increasing number of migrants in the Czech Republic. Nevertheless, it is not possible to determine the exact number of these experiences with respect to the length of practice and the frequency of contact with migrants.

All interviews were conducted by prior arrangement and with the consent of a particular healthcare professional, while the choice of location was left to the preference of the interviewee. They almost always preferred to hold the interview inside the healthcare setting in a separate room that served as a medical or nursing room. The duration of the interviews varied depending on the circumstances of the interview. Some had to be terminated prematurely, while others were interrupted several times. Nevertheless, the average length of interviews was 80 minutes. A number of these professionals refused the audio recording of the conversation. For that reason, I took notes and wrote down all keywords during the interview, and transcribed each conversation with the aid of the detailed notes as soon as possible. The conversations that were recorded with the interviewees' consent were transcribed verbatim. Furthermore, non-participant observations were conducted during the research to record the behaviour of individuals, and what 
they were doing and saying within the given setting. Thus my position did not interrupt the healthcare professionals' work or the interactions that took place. In addition, informal interviews were conducted as I moved freely around the ward, always addressing and introducing myself as a researcher. Data collection was terminated when the analysed topics were repeated, and further observations and interviews did not yield new information.

All data, including field notes and informal interviews, were subsequently read repeatedly and coded by open coding (Hendl, 2005). The data were analysed by so-called thematic analysis. Using this analysis, emerging and recurring themes and sub-themes related to strangeness, categorization of women, and conceptualization of "fine patients" were revealed. Adjectives were also coded as attributes that constituted the category of women. Although other methods of collection were used during the research, the findings presented in this text come mainly from data from the in-depth interviews; comparisons between healthcare facilities did not reveal significant differences.

The research strictly followed ethical principles for conducting research according to the Code of Ethics of the American Sociological Society (ASA, 2018). Each of the healthcare professionals addressed was familiarized with the details and intent of the research, as well as with the principles of anonymity being ensured. All participants were given the opportunity to refuse the interview or to withdraw from it during its course. The provision of verbal informed consent was a condition for participation in the research. All the names in this text are fictitious, and excerpts from the interviews illustrate the presented findings with regard to the aptness of the statements.

\section{Results}

\section{Strangeness and country of origin: Who is a foreigner?}

Strangeness with regard to the country of origin was to a certain extent predefined by the research plan. I purposefully asked individual healthcare professionals about their experiences with women "who were not born in the Czech Republic" in order to avoid the initial categorization on my part. Despite this, my question was unclear for healthcare professionals, and they requested clarification on who the woman not born in our country are, as well as the need to "pigeonhole" these women.

For example, doctor Bedřich, like the other healthcare professionals, asked me at the beginning of the interview: "Who do you mean?" Following this he immediately added: "Well, look, we don't have those wretched individuals with a backpack on their back." Healthcare professionals demanded clear information about the origin of women, which was a crucial classification criterion for them in relation to how they see and label these women.

This need for clarification pointed to the relatively clear categorization of women: the first category contains foreigners who "came here" and those with whom it is possible to come into contact with in everyday life.

"So, experiences with foreigners... and who do you mean? Well, the question is, who is it? What nationality do you mean? Because here, we have our foreigners who normally live here, work here (...)" (doctor Bedřich).

"With women who were not born here? And who are they for you? Because we have a lot of such women here. (...) And do you also mean Slovak women? So, they (Slovak women) are ours, right? I don't consider them foreigners" (Marie, midwife).
From the statements of healthcare professionals, the first category - "our foreigners" - can be used to designate all those who have lived in the Czech territory for many years, are employed here, have families here, and of whom it's possible to say they are integrated. Likewise, other healthcare professionals often emphasized in the interviews the necessary distinction between women (or their nationality in general) considered "foreigners" and those considered "migrants". For example, the midwife Marie stated that she did not consider Slovak women to be foreigners at all, mainly because of the former state of Czechoslovakia - which disappeared in 1992. Although currently residents of another state, inhabitants of Slovakia are still considered to be very close people, who, in the recent past, shared the same state - and as such, the same culture.

On the other hand, the second category of "migrant women" refers to women whose stay in our territory is not permanent, or whom the healthcare professionals do not meet as often as other foreigners ("ours").

"And what are you interested in? We have a lot of Ukrainian women and Vietnamese women as we have different nationalities here, but not on a large scale. And we don't have a typical refugee with a backpack, not at all. We have here like, sometimes some rich Russians come, and sometimes a poor Ukrainian or some Vietnamese comes, who have the greatest language barrier. Or Arabs; people from the Arab states sometimes come here in pupa (...)" (doctor Antonín).

"(...) And then there are black women and other nationalities that migrate. But we don't have them here" (doctor Bedřich).

For healthcare professionals, this initial categorization points to their customary idea of who is a "migrant" and who is ("our") "foreigner" - who is part of their daily practice and who is not. Healthcare professionals often associate the notion of "migrant" with refugees, especially from the Middle East and Africa, who are still migrating and, as some of them have emphasized, "We do not meet them so much." This categorization of migrant women refers to strangeness, which is based firstly, on cultural and geographical diversity or distance, and secondly, on visible features, such as body-enveloping (face veil) or skin colour that are connected to a given culture and ethnicity. For example, the midwife Verra stated: "So those Romanian women, Ukrainian women, Russian women, it's no trouble for me; their culture is similar to ours, after all. Even the language."

\section{Strangeness, language and childbirth: "Fine patients" or silent sufferers?}

Another important aspect that contributes to the formation of strangeness and some differences in interactions between healthcare professionals and migrant women is knowledge of the official language. Most healthcare professionals began their narrations about experiences with migrant women with a certain reflection of the care provided, its quality, and with an evaluation of migrant women as recipients of care. This illustrates the assertion of the midwife Tereza, who looked at migrant women as problem-free "good patients" and emphasized that the care provided to foreigners (migrant women in general) is the same as the care provided to native women:

"So, we do not have a problem with them, and the care is the same. Well, the foreigners we have here are fine patients. There is no problem with them" (Tereza, midwife).

Tereza was not the only one; other healthcare professionals defined the provided care and evaluated it as unproblematic and not differing due to the recipients of care being foreigners. This tendency, emphasized at the beginning of the interview, may refer to justification and affirmation of equal access and 
equal quality of care, regardless of the nationality of the recipient. Health care is one of the protected areas where different treatment of people on the basis of distinct race, ethnicity, or nationality is illegal (Act No. 198/2009 Coll.). As the statements from the interviews show, the members of the medical team have the principles of equal treatment in mind.

Tereza subsequently evaluated the foreigners as fine, and such statements were heard in many interviews. The perception of foreigners as trouble-free "fine patients" with whom there are no serious difficulties or disagreements prevailed. It is important to highlight that, despite the significant influence of market principles, women are still very often labelled as "patients", not "clients" (Hrešanová, 2008).

Primarily, the trust of healthcare professionals gained through our long conversations enabled me to deeply understand the frequent judgment: "Yeah, they are fine patients." It revealed the problem of seemingly trouble-free foreigners in relation to health care.

It is not surprising that the most serious problem to obstruct the interaction is the language barrier and limited communication skills (Balaam et al., 2013). However, equally important is how this barrier affects the relationship and how it forms the manner of communication and cooperation between those involved in a given context and situation. From my observations and interviews, it emerged that the importance of the language differs depending on the department and the period of care that migrant women receive. Data analysis revealed that the term "fine patient" is most often mentioned by healthcare professionals in the midwifery department. This positive picture of women, that may suggest proximity, consists in women's approach to healthcare staff and to received care. It is characterized by "obedience" and trust. Healthcare professionals talked about these "fine" women as those who come without the typical demands and claims relating to care and childbirth, as well as those who are grateful for the provided care. As the midwife Markéta stated: "They (migrant women) allow us to do what we need."

"(...) So, these migrant women, they're fine, they don't dictate anything. Although for example, they don't understand at all, that is also a problem, but if they cooperate with us, the childbirth goes smoothly. (...) There are no problems with those migrant women. Mostly they allow us to do what we need to" (Markéta, midwife).

In her narrative, Midwife Markéta emphasized that migrant women often do not understand and admitted that language barriers are a problem when in contact with them. Nevertheless, she framed the experiences with them by indicating they were "fine" women who do not dictate and do cooperate. According to healthcare professionals, the ability to cooperate is a crucial determinant of the positive assessment of women in relation to care. The positive picture of migrant women is shaped by passivity, loyalty, and above all, silence. The vast majority of migrant women have limited ability to communicate in the Czech language, and it also limits their ability to verbalize anything (Robertson, 2015).

Ignorance of the language and the impossibility of communication and mutual understanding is undoubtedly connected with a certain strangeness, something that is unusual, different and distant for the majority society. However, there is a contradiction in the institutional care setting, particularly in the midwifery department, where this strangeness is perceived more positively and substituted by other forms of communication. Healthcare professionals emphasized that they do not need language (verbal communication) at all for childbirth; "we always understand each other."
"(...) And I think that, specifically during the childbirth, it (the language barrier) also increases the pain, because if she does not understand us well and she can't simply explain what she wants, it must absolutely multiply the stress and multiply the pain, and therefore the woman's perception of the birth can be logically worse for her. At that moment, you are doing everything you can... for example you somehow convey what she has to do with gestures. But it also has to be more demanding for her, in terms of stress (...)" (Viktorie, midwife).

Midwife Viktorie spoke about the language barrier she often encounters in the context of everyday practice, and reflected on its problematic nature and seriousness. She is aware that a migrant woman may not be completely without demands and wishes (as other healthcare professionals stereotypically presume), and she expects that unspoken wishes may be hidden behind the "silence" - wishes a migrant woman is not able to communicate. At the same time, midwife Viktorie points to the routinization of the profession. In the case of a language barrier, this routinization puts healthcare professionals in a situation in which they "act out" all care and necessary information "through gestures". As healthcare professionals often emphasized in their statements, they automatically choose a non-verbal way of communicating and communicate "by arms and legs" in the case of an inability to communicate with a woman. Various gestures, facial expressions, and signals replace verbal communication. This form often becomes the only tool of communication, because the majority of migrant women come without an interpreter (Pařízková et al., 2018). Some migrant women come with their husband or another family member. Another common practice, but only with Vietnamese women, is to have an interpreter on the phone (Jelínková, 2007). However, healthcare professionals do not consider this practice as positive, because of the continuous handing of the phone back and forth, which makes the course of examination or childbirth more difficult.

For example, midwife Viktorie stated that "it's interesting, but few women bring an interpreter". Despite this fact, healthcare professionals consider non-verbal communication to be an adequate means of interacting with a woman giving birth.

"It always goes along somehow, but it's uncomfortable. They (migrant women) know some words for showing that they want something for pain - a painkiller. We have always understood each other. It always turns out fine. The advantage is that birth is largely a physiological matter. Another situation is for example in the ward of internal medicine, where you have to explain some procedure or process to the woman. And here they mostly know the process of giving birth and know what to expect. So gestures are enough, the non-verbal communication is sufficient, but it's uncomfortable for all of us (she paused)..." (midwife Žaneta).

Some healthcare professionals rationally justify the relative unimportance of verbal communication by the fact that childbirth is a physiological matter. According to them, every woman knows what to expect, what to be prepared for, what to do, and what will follow. However, this means women remain in a state where they are not (or are only partially) informed. Occasionally, they are not familiar with the course of childbirth and often they may not understand individual gestures. According to the professionals, such patients either give a nod to everything as if they understand, or they remain silent. Some midwives considered the situation in which migrant women find themselves and described them as "silent sufferers." This indicates the highly vulnerable position of migrant women in the context of institutional care. 
"Mostly these women are cooperating. As they don't speak, they suffer quietly. They are not hysterical, they are kind" (Kateřina, midwife).

"Most of them are such silent sufferers. They simply know that they must somehow survive" (Barbora, midwife).

\section{Strangeness of women and care: Who is the right patient?}

Although experiences with migrant women in the birthing process were described mainly as problem-free, the importance of verbal communication is assessed differently in other situations and in other wards. According to the midwives from the prenatal department, the language barrier makes the first meeting problematic, for example when they have to arrange the date of the first visit or examination with a migrant woman (Robertson, 2015). A lengthy explanation of what date and the documents a woman has to bring is demanding for professionals and often "disrupting to the system".

"They (migrant women) don't understand; they often respond to something else, and we can't get the information that we want from them by phone. But we are counting on the particular date. We need to make an appointment with the woman for the specific date. But they come on another date, or they come more often, because we can't agree on a date by phone. It's a treadmill of ordering. (...) Some women come uninsured, so we send them to the Foreigners Department to arrange the papers before the examination and to pay the deposit. But they don't bring the papers that we need, so we send them back there, and they are scared about why (...). So they spend more time here, but one failure disrupts the whole system (...)" (Alžběta, midwife).

The excessive administrative steps not only make the position of migrant women difficult in the context of institutional care, but also cause problems for healthcare professionals performing their duties because they are required to obtain and complete individual documents such as medical history (anamnesis), medical record, birth record and informed consent form for the provision of health care and/or hospitalization (Act No. 372/2011 Coll.). The language barrier significantly disrupts the relationship and cooperation between healthcare professionals and migrant women in the context of prenatal care. As a result of certain situations, migrant women are often perceived as problematic, irresponsible, and disruptive to the system, and are negatively assessed by healthcare professionals. Ignorance of the language, but also of the system, negates the positive picture of a migrant woman as a "fine patient." This raises the question: who is the right patient, from the perspective of healthcare professionals?

Data analysis points to the varying importance of language in different stages of care and in different institutional contexts. Different stages and contexts affect the extent to which ignorance of the language is a "problem" for the cooperation or responsibility of migrant women, from the perspective of healthcare professionals. Furthermore, healthcare professionals use the categorization of women by nationality, with which they associate different labels according to women's approach to care. For example, Russian women are often perceived as "haughty", "arrogant", and refusing to communicate. In contrast, Vietnamese women, "those Nguyen", are considered "adaptable", "grateful", "kind and diligent", even when they do not understand. Arab women, "quiet" and "silent", and Vietnamese women are characterized by a complete language barrier. Nevertheless, some professionals consider Arab women to "treat professionals as if they are servants". According to the statements, there are no problems with Ukrainian or Slovak women: they mostly live here, work here, they are "humble" or "like us". The assessment of Ukrainian women's approach to care is illustrated by Viktorie's argument about the quality of health care in the country of origin.

"But mostly they (migrant women) don't have any demands and requirements. Mostly, for example Ukrainian women, they are in needy situations here. Because they come here, and often they are university-educated women who work here as unskilled labourers. So, it is a tolerant nation that comes and accepts our care. The large part of them speak Czech, if not totally, at least partially. They have assimilated well. They are mostly humble. They usually come from some other circumstances that they are glad to be here and that (our) care is better than in Ukraine. And they have it like that - it's by choice. I have heard comparisons of the health care, that they would not get that kind of care there, that the care in Ukraine is worse and for the same money. So why not choose something for the same money that offers more comfort. And I think that they feel this way. And they are mostly normal nice women" (Viktorie, midwife).

On the other hand, according to healthcare professionals, Bulgarian and Romanian women are often uninsured, undisciplined on the issue of risk behaviour, and also poorly proficient in language. Professionals often compare these women with Roma women who are described as "spontaneous", "natural", but "undisciplined" and "unruly", Healthcare professionals explain these labels as women's impudence and arrogance, their use of vulgar expressions or smoking. On the other hand, some professionals admitted that Roma women are very respectful, especially towards doctors.

Despite the significant language barriers and negatives associated with communication difficulties, and even despite the fact that migrant women are often considered undisciplined or unruly, migrant women are generally perceived quite positively by professionals. As some of the professionals claimed, "Migrant women don't surprise us by anything, and they are good! Except for language and insurance" (Monika, midwife). However, we can say that this positive category of migrant women is shaped through a comparison with Czech women. Healthcare professionals literally created a "new foreign nationality", which is Czech women.

Midwife Jana: "We could classify alternative women as a foreign nationality. These are the foreigners. They have a different language than we do. We don't understand them. We cannot communicate with those 'alternatives' (alternative women). They are scary."

Researcher: "In what sense?"

Midwife Jana: "They think only of themselves. You tell them (alternative women) something that they should do for an unborn child. For example, the monitor isn't very good, that she (an alternative woman) should do something, and she isn't willing to change anything at all, like to change her position for labour, and she doesn't want to change it. They should breathe as recommended and at least behave decently. But they come and say to us directly: 'You will not do anything, everything will be as I see it.' And they already have that approach when you meet them - not nice: 'Hello, I am the one and do you think you will accept my wishes?' Not at all! They (alternative women) come and react harshly. So you have to approach it as a professional and survive it somehow. And work with them patiently... that is quite demanding. Especially when they have a doula."

Not only Jana but also other healthcare professionals frequently compared their experiences with migrant women and Czech women. Despite the shared language, interactions with Czech women were assessed by professionals as more problematic. According to the professionals' statements, Czech women are generally "spoiled by service", very often distrustful and contrary towards professionals, which causes problems 
in communication and cooperation with them. This approach of Czech women is usually illustrated in the sample birth plans they come up with. Such birth plans contain their requirements and wishes.

"The biggest problem is Czech women and their birth plans. Mostly primiparas have birth plans. But they have it (birth plan) downloaded from the Internet and don't understand it. In addition, these women are aggressive, and usually when they come they are aggressive, unpleasant, and immediately there is a problem. They pull out the birth plan, and this totally undermines confidence in us. And from then on, the relationship is poorly established; sometimes it isn't established at all. (...) It's like these women are doing it on purpose and they are 'opposed' on purpose. And the communication is not good! You put the woman in tune, agree with her, and mostly these women don't give birth smoothly, because they don't tune in, don't communicate, or don't agree with you. (...) Nowadays they can ask for anything, and we don't impose anything on them. It's about communication. But there is always a problem with them, they are 'trouble-makers"' (Blanka, midwife).

The birth plan, as a "Czech reservation", is perceived as undermining trust in healthcare professionals and questioning medicine. Furthermore, according to healthcare professionals, a birth plan with an individual woman's requirements has a negative impact on cooperation and building a mutual relationship. According to midwife Blanka, poor communication affects the "tuning," and the overall course of childbirth doesn't go smoothly because of that.

"They give us the paper (birth plan) and don't talk about their wishes." This is how healthcare professionals evaluate the approach of so-called "trouble-makers", "bio mothers", "alternative", or "tragic women". These are the labels used for Czech women who come with specific requirements, especially with an emphasis on non-invasiveness and the absence of medical intervention. Healthcare professionals consider this approach as inconsiderate to the unborn child. According to them, these women are not considering the risks that may arise as a result of "insisting on" or rejecting the recommended procedures. Childbirth is "an unrepeatable experience and nobody ever knows how it will be" (midwife Markéta). Writing something out before childbirth is regarded by professionals as nonsensical and wrong.

\section{Discussion}

\section{Vulnerability of migrant women}

Migration is one of the most serious sources of vulnerability (Rogers, 1997), involving the social, cultural, and political conditions of the recipient country in connection with relocation to a new country (Delor and Hubert, 2000). The findings from this research point to the very vulnerable situation of migrant women in the context of institutional (health) care. The language barrier is one of the most discussed and crucial topics, but the "silence", "quietness", and "obedience" of migrant women are interpreted positively by healthcare professionals. However, it is necessary to consider the strong negative effects of this "silence" and the women's lack of information, especially in the absence of an interpreter. If a woman is not able to verbalize her questions or requests because of ignorance of the language, healthcare professionals do not have the opportunity to explain all the information in the woman's maternal language. According to some professionals, the woman literally "suffers silently" in childbirth. An even more serious situation arises in the case of urgent complications during delivery; when professionals have to act quickly but without communi- cation, they may waste time searching for a way to interpret and explain everything to the woman. Although healthcare professionals hold the view that women "sense it and understand it" (complications, the urgent need of medical intervention), migrant women can often experience severe stress or suffering and gain a negative experience of childbirth, which opens up a number of other potential negative effects on both the woman and the child (Beeckman et al., 2009).

The presence of professional interpreters who could become part of everyday practice would contribute to the elimination of such situations and to the improvement of the position of migrant women in the context of perinatal care (and the overall healthcare system). Healthcare professionals are helpless in these situations and unable to provide interpretation or translation of information that must be communicated to or obtained from patients. Migrant women are very vulnerable in the context of institutional care, not just because they do not know the official language and cannot speak $C z e c h$. The state of vulnerability is shaped by more factors arising from the context, situation, and personality of the woman, and these factors may intersect. The vulnerability of women and their experiences should be regarded as structural. The structural vulnerability of women emphasizes the positionality of marginalized individuals within the system. An inappropriate position within the system can endanger the health, quality of care, and the experience of receiving care (Inhorn, 2018).

\section{Strangeness and stigma}

Strangeness can be understood as something not one's own that is different or diverse (Dictionary of the Standard Czech Language). Strangeness is closely related to stigma. Stigma is created "as a result of delimiting oneself towards an individual's distinctiveness or strangeness" (Goffman, 2003, pp. 11-13). However, this difference may not always be evident at first sight, as illustrated by the statements of healthcare professionals. In the case of migrant women, a negative stigma arises not only because of a different ethnicity, but also causes and reinforces the women's language barrier and their ignorance of the system and cultural norms that may affect their access to care. All of this disrupts the daily medical routine and does not correlate with the expectations of healthcare professionals. This fact reinforces the label of "undisciplined" and "disruptive" women.

It is noteworthy that the healthcare professionals did not reflect on the causes of the women's ignorance, lack of knowledge or their different approach during the interviews (which can be many with regard to their socio-cultural origin). For example, the healthcare system in their country of origin may be set up differently, or pregnancy and childbirth may not even be part of institutional care (Hoban and Liamputtong, 2013). From my point of view, the issue of language barriers is also crucial. Although healthcare professionals often asserted during conversation that they "don't need language," meaning that it is not necessary to communicate with a woman verbally, and that non-verbal gestures are adequate for them to understand (the gestures themselves may vary from one culture to another). As a result, migrant women may not understand particular gestures, or they may read their meaning differently (Straus et al., 2009). The healthcare professionals' perception of such patients as "bad", the women's stigmatization, neglecting the causes of their stigma at the social level, undoubtedly leads to exacerbating their disadvantaged position and a replication of social inequalities (Sointu, 2017). The healthcare system in general should pay more attention to the different socio-cultural origins of patients, providing care to migrant 
individuals more sensitively, and reflect on attempting to understand their differences.

\section{The right patient}

Delimitation towards strangeness in interactions with women, from the perspective of the healthcare profession, led me to consider the question of who the right patient is. Although we might assume that the right patients are women sharing the same culture and language, as the findings described above reveal, the reality is different. The right patient, according to healthcare professionals, is a migrant woman who trusts, cooperates, and "does everything" the professionals want and need - that is, she conforms to the normality of their expectations. Czech women, especially "alternatives" and "trouble-makers", represent "strange" women who do not comply with this norm of the "right patient". Childbirth and its individual experiences are framed by the standards of biomedical discourse and, at the same time, by surviving paternalism, when women are disempowered and expected to be passive and conformist (Chadwick, 2018). Excessive paternalism, lack of staff (and its frequent changing), or neglect of individual needs and wishes can affect each woman's experience of childbirth and her overall experience in the context of perinatal care, in which, above all, they may lack individual and continuous care.

\section{Conclusions}

The analysis of data shows that healthcare professionals distinguish two categories of foreign (not Czech) women within their daily routine: "our foreigners" and "migrant women". This categorization is established through a certain closeness, both geographical and cultural, and through visible features. Furthermore, this category is conditioned by their integration, especially participation in the labour market. The experiences of healthcare professionals with migrant women are framed by the discourse of "fine patients", which captures the situation of migrant women, especially those who do not speak Czech, in the context of institutional care. The language arises as a key mechanism in the interaction between healthcare professionals and women. However, the language barrier is not always perceived as a major barrier, such as while giving birth. In this event, "quiet" women do not make demands or have requirements; they give the okay to everything and agree with everything the professionals suggest. These women earn the label of "obedient" women who "do what healthcare professionals need". Their passivity is evaluated positively in the view of healthcare professionals, because the routine of everyday medical practice is not disrupted, and the expert authority isn't questioned. "Fine patients" reconfirm the power imbalance between women and healthcare professionals. It may be said that, from this point of view, the strangeness of these women is not unfamiliar, if they trust and cooperate.

Healthcare professionals established a new category of foreigners, namely Czech women. Their strangeness is based on an active and questioning role and distrust. This distrust is manifested by the birth plan and the women's demands, along with their negative and resistant approach, which causes their inability to cooperate and communicate. The strangeness of Czech women in their interactions is perceived by healthcare professionals as more problematic than the geographical or cultural differences of migrant women.

The findings from this research cannot be generalized. This is not only due to the low number of health facilities and indepth interviews included, but also because of the specificity of experiences. Nevertheless, it can be stated that the dissimilarity and strangeness of women are perceived through various characteristics conditioned by individual, contextual and situational factors, which at the same time shape the experience of women's vulnerability. Migrant women are most often stigmatized negatively, but also positively, and this significant positive stigma lies in their "obedience". In the case of Czech women, a strong stigma is caused by their approach to care, resistance and non-cooperation. As a result of this stigmatization of Czech women, healthcare professionals agreed with the opinion that is best illustrated by a direct quotation from midwife Viktorie: "So when such a Czech woman with a birth plan comes, or when a Vietnamese woman comes who does not speak Czech, Vietnamese is better than Czech!" Healthcare professionals emphasized the problematic nature of their interactions with the Czech women, and they paradoxically perceived the care for migrant women more positively - even at the cost of a significant language barrier and the complexity of individual procedures or examinations.

\section{Conflict of interests}

The author has no conflict of interests to declare.

\section{Acknowledgement}

This text was supported by the project "Migration and maternal health: pregnancy, birth and early parenting" (Czech Science Foundation, Grant No. 16-10953S).

\title{
„To radši Vietnamku než Češku“: Cizost v interakcích mezi zdravotníky a ženami v kontextu perinatální péče
}

\begin{abstract}
Souhrn
Období těhotenství, porodu a stávání se matkou jsou jedny z nejzásadnějších momentů v životě každé ženy, zpravidla prožívaných $\mathrm{v}$ prostředí institucionální péče. To však může přinášet celou řadu potíží a bariér v př́ípadě žen nenarozených v České republice a ovlivnit interakce mezi nimi a zdravotnickým personálem. Cílem textu je objasnit, jak je ustavována kategorie cizinky a co znamená „cizost“ pro zdravotnice a zdravotníky ve vztahu k ženám v prostředí perinatální péče. Byl proveden kvalitativní výzkum, který se zaměřoval na zkušenosti zdravotnického personálu s ženami odlišné národnosti, v rámci něhož byly realizovány hloubkové rozhovory, pozorování a rozhovory neformální. Zdravotníci a zdravotnice v rámci své každodennosti rozlišují dvě kategorie žen nenarozených na území českého státu - „naše cizinky“ a „migrantky“ - s ohledem na geografickou a kulturní blízkost. Cizinky jsou pak obecně vnímány jako „poslušné“ pacientky, které nenarušují rutinu každodenní medicínské praxe. „Cizost“ je zdravotníky a zdravotnicemi interpretována v interakcích se ženami, a to zejména z důvodu problematické komunikace, spolupráce, nedůvěry a zpochybnění ze strany žen.
\end{abstract}

Kličová slova: cizost; jazykové bariéry; komunikace; migrace; perinatální péče; stigma 


\section{References}

1. Act No. 198/2009 Coll., of 23 April 2008, on equal treatment and on the legal means of protection against discrimination and on amendment to some laws (the Anti-Discrimination Act). In: Collection of Laws of the Czech Republic.

2. Act No. 372/2011 Coll., of 6 November 2011, on health services and conditions of their provision. In: Collection of Laws of the Czech Republic.

3. Aday LA (1994). Health status of vulnerable populations. Annual Reviews of Public Health 15: 487-509. DOI: 10.1146/ annurev.pu.15.050194.002415.

4. ASA (American Sociological Association) (2018). Code of ethics. [online] [cit. 2019-01-02]. Available from: http://www.asanet. org/sites/default/files/asa_code_of_ethics-june2018.pdf

5. Balaam MC, Akerjordet K, Lyberg A, Kaiser B, Schoening E, Fredriksen AM, et al. (2013). A qualitative review of migrant women's perceptions of their needs and experiences related to pregnancy and childbirth. J Adv Nurs 69(9): 1919-1930. DOI: 10.1111/jan.12139.

6. Beeckman K, van De Putte S, Putman K, Louckx F (2009). Predictive social factors in relation to preterm birth in a metropolitan region. Acta Obstet Gynecol Scand 88(7): 787-792. DOI: 10.1080/00016340902974007.

7. Chadwick R (2018). Bodies that birth: vitalizing birth politics. Abingdon, New York: Routledge.

8. Czech Statistical Office (2018). Foreigners in the Czech Republic - 2018. [online] [cit. 2019-01-02]. Available from: https://www.czso.cz/csu/czso/foreigners-in-the-czechrepublic-2018

9. Delor F, Hubert M (2000). Revisting the concept of 'Vulnerability'. Soc Sci Med 50(11): 1557-1570. DOI: 10.1016/ S0277-9536(99)00465-7.

10. Goffman E (2003). Stigma: poznámky k problému zvládání narušené identity. Praha: SLON.

11. Hašková H (2001). Názorové diferenciace k současným změnám v českém porodnictví. Praha: Sociologický ústav AV ČR.

12. Hendl J (2005). Kvalitativní výzkum: Základní metody a aplikace. Praha: Portál.

13. Hnilicová H, Dobiášová K, Čižinský $P$, Studený L, Juránek J (2012). Analýza komerčního zdravotního pojištění cizinců. [online] [cit. 2019-01-05]. Available from: http://www.osf.cz/ wp-content/uploads/2015/08/Analyza_Konzorcium_final.pdf

14. Hoban E, Liamputtong P (2013). Cambodian migrant women's postpartum experiences in Victoria, Australia. Midwifery 29(7): 772-778. DOI: 10.1016/j.midw.2012.06.021.

15. Hrešanová E (2008). Kultury dvou porodnic: etnografická studie. Plzeň: Vydavatelství ZČU.

16. Hrešanová E (2011). Birth care and the experience of Czech women: a qualitative study. Gender, rovné př́ležitosti, výzkum 12(2): 63-74.

17. Hrešanová E, Glajchová A (2018). The elderly and foreigners: vulnerability and intersectionality in healthcare. Gender and Research 19(2):75-101. DOI: 10.13060/25706578.2018.19.2.4 27.

18. Hrešanová E, Hasmanová Marhánková J (2008). Nové trendy v českém porodnictví a sociální nerovnosti mezi rodičkami. Sociologický časopis 44(1): 87-111.

19. Inhorn MC (2018). America's Arab refugees: vulnerability and health on the margins. Redwood City, California: Stanford University Press.

20. Jelínková M (2007). Přístup (ne)legálních migrantů ke zdravotní péči. [online] [cit. 2019-01-07]. Available from: http://migraceonline.cz/cz/e-knihovna/pristup-ne-legalnichmigrantu-ke-zdravotni-peci

21. Liamputtong P (2006). Motherhood and "moral career": Discourses of good motherhood among Southeast Asian immigrant women in Australia. Qual Soc 29(1): 25-53. DOI: 10.1007/s11133-005-9006-5.

22. Pařízková A, Hrešanová E, Glajchová A (2018). Migration and childbirth: An Intersection of Two life changes in Social Science research on Women's Health. Sociologický časopis 54(1): 63-99. DOI: 10.13060/00380288.2018.54.1.396.

23. Robertson EK (2015). 'To be taken seriously': women's reflections on how migration and resettlement experiences influence their healthcare needs during childbearing in Sweden. Sex Reprod Healthc 6(2): 59-65. DOI: 10.1016/j. srhc.2014.09.002.

24. Rogers AC (1997). Vulnerability, health and health care. J Adv Nurs 27(1): 65-72. DOI: 10.1046/j.13652648.1997.1997026065.x.

25. Slepičková L, Šmídová I (2014). Postoje českých lékařů $\mathrm{k}$ medicíně a ke změnám $\mathrm{v}$ praxi reprodukční medicíny. Data a výzkum-SDA 8(1): 63-95. DOI: 10.13060/23362391.2014.8.1.110.

26. Slovník spisovného jazyka českého. [online] [cit. 2018-12-22]. Available from: http://ssjc.ujc.cas.cz

27. Sointu E (2017). 'Good'patient/'bad'patient: clinical learning and the entrenching of inequality. Sociol Health Ill 39(1): 63-77. DOI: 10.1111/1467-9566.12487.

28. Straus L, McEwen A, Hussein FM (2009). Somali women's experience of childbirth in the UK: perspectives from Somali health workers. Midwifery 25(2): 181-186. DOI: 10.1016/j. midw.2007.02.002. 